EL MUHASABA: Jurnal Akuntansi (e-Journal)

Volume 11, No. 2, Tahun 2020

P ISSN: 2086-1249; E ISSN: 2442-8922

\title{
PENGUNGKAPAN ISLAMIC CORPORATE SOCIAL RESPONSIBILITY (ICSR) DAN GOOD CORPORATE GOVERNANCE (GCG) TERHADAP NILAI PERUSAHAAN DENGAN KINERJA KEUANGAN SEBAGAI VARIABEL INTERVENING)
}

\author{
Reistiawati Utami ${ }^{1}$, Meina Wulansari Yusniar ${ }^{2}$ \\ Universitas Lambung Mangkurat ${ }^{1,2}$ \\ Jalan Brigjen H. Hasan Basri, 70123, Indonesia \\ e-mail: reisti.utami@gmail.com ${ }^{1}$
}

\section{Abstract}

The company maintains its existence by maintaining the company's financial performance and establishing its good relations to its stakeholders. Islamic Corporate Social Responsibility (ICSR) and Good Corporate Governance (GCG) are forms of corporate responsibility towards its stakeholders. This study aims to analyze the effect of disclosures of ICSR and GCG on the Company Profitability and the Company Value through Company Profitability.

The proxy variables used are the ISR Index (Islamic Social Reporting), the GCG Index sourced from KNKG and OJK, ROE and PBV. Companies chosen as the sample of research are those included in JII for the period 2016 - 2018. Data analysis and hypothesis testing were conducted through the Mediation effect Regression technique by using the SEM - PLS algorithm generated by Smart PLS 3.0 software.

The results showed that (1) ICSR had a negative and insignificant effect on Company Financial Performance, (2) ICSR had a negative insignificant effect on Company Value, (3) GCG had a significant positive effect on Company Financial Performance, (4) GCG had a positive and significant effect on Company Value,(5) Financial Performance had a significant and positive effect on Company Value,(6) Financial Performance could not mediate the relationship of ICSR influence on Company Value, and (7) Financial Performance could mediate the relationship of GCG influence towards Company Value.

Keywords: ICSR, GCG, Company Performance, Firm Value

\section{Abstrak}

Perusahaan mempertahankan kelangsungan hidupnya dengan menjaga kinerja keuangan perusahaan dan menjaga hubungan baik dengan para stake holder nya. Islamic Social Responsibility (ICSR) dan Good Corporate Governance (GCG) merupakan bentuk pertanggung jawaban perusahaan terhadap para stake holder nya. Penelitian ini bertujuan untuk menganalisa pengaruh pengungkapan ICSR dan GCG terhadap Kinerja Keuangan Perusahaan dan Nilai Perusahaan melalui Kinerja Keuangan Perusahaan.

Proksi variabel yang digunakan adalah Indeks ISR (Islamic Social Reporting), Indeks GCG yang bersumber dari KNKG dan OJK, ROE serta PBV. Sampel Perusahaan adalah perusahaan yang masuk dalam JII periode 2016 - 2018. Analisa data dan pengujian hipotesis dengan teknik Regresi efek Mediasi menggunakan algoritma SEM - PLS melalui software Smart PLS 3.0.Hasil penelitian menunjukkan bahwa (1) ICSRberpengaruh negatif tidak signifikan terhadap Kinerja Keuangan Perusahaan, (2) ICSR berpengaruh negatif tidak signifikan terhadap Nilai Perusahaan, (3) GCG berpengaruh positif signifikan terhadap Kinerja Keuangan Perusahaan, (4) GCG berpengaruh positif signifikan terhadap Nilai Perusahaan, (5) Kinerja Keuangan berpengaruh positif signifikan terhadap Nilai Perusahaan, (6) Kinerja Keuangan tidak mampu memediasi hubungan pengaruh ICSR terhadap Nilai Perusahaan, (7) Kinerja Keuangan mampu memediasi hubungan pengaruh GCG terhadap Nilai Perusahaan.

Kata Kunci: ICSR, GCG; Kinerja Keuangan, Nilai Perusahaan

\section{PENDAHULUAN}

CSR (Corporate Social Responsibility)atau juga disebut Tanggung Jawab Sosial Perusahaan merupakan konsep yang muncul dari kesadaran bahwa setiap keputusan 
Reistiawati Utami dan Meina Wulansari Yusniar : Pengungkapan Islamic Corporate Social Responsibility (ICSR) dan Good Corporate Governance (GCG) terhadap Nilai Perusahaan dengan Kinerja Keuangan sebagai Variabel Intervening

dan tindakan yang dilakukan oleh perusahaan akan menghadirkan konsekuensi pertanggung jawaban atas dampak negatif maupun positif yang ditimbulkan dari keputusan dan tindakan tersebut. Diskusi CSR terus mengarah pada bentuk yang lebih kompleks dan tujuan yang lebih beragam. CSR tidak hanya sekedar memenuhi apa yang menjadi sebatas kewajiban Perusahaan, namun CSR berkembang pada tataran strategi jangka panjang perusahaan untuk mempertahankan keberadaanya dan untuk memperoleh pengakuan dari lingkungan dan pihak pihak yang berkepentingan dengan perusahaan yakni para stake holder.

Investor sebagai salahsatu stake holder perusahaan mempertimbangkan faktor kinerja ekonomi perusahaan dan faktor lainnya yakni faktor sosial dan lingkungan yang dapat menunjang keberlangsungan perusahaan.Terjadi peningkatan jumlah perusahaan terbuka di Bursa Efek Indonesia (BEI) yang menerbitkan Laporan Keberlanjutan dalam beberapa tahun terakhir. Peningkatan ini menunjukkan bahwa pengungkapan aktivitas tanggung jawab sosial Perusahaan merupakan issue potensial yang menjadi perhatian para stake holder dan dapat menunjang keberlangsungan perusahaan.

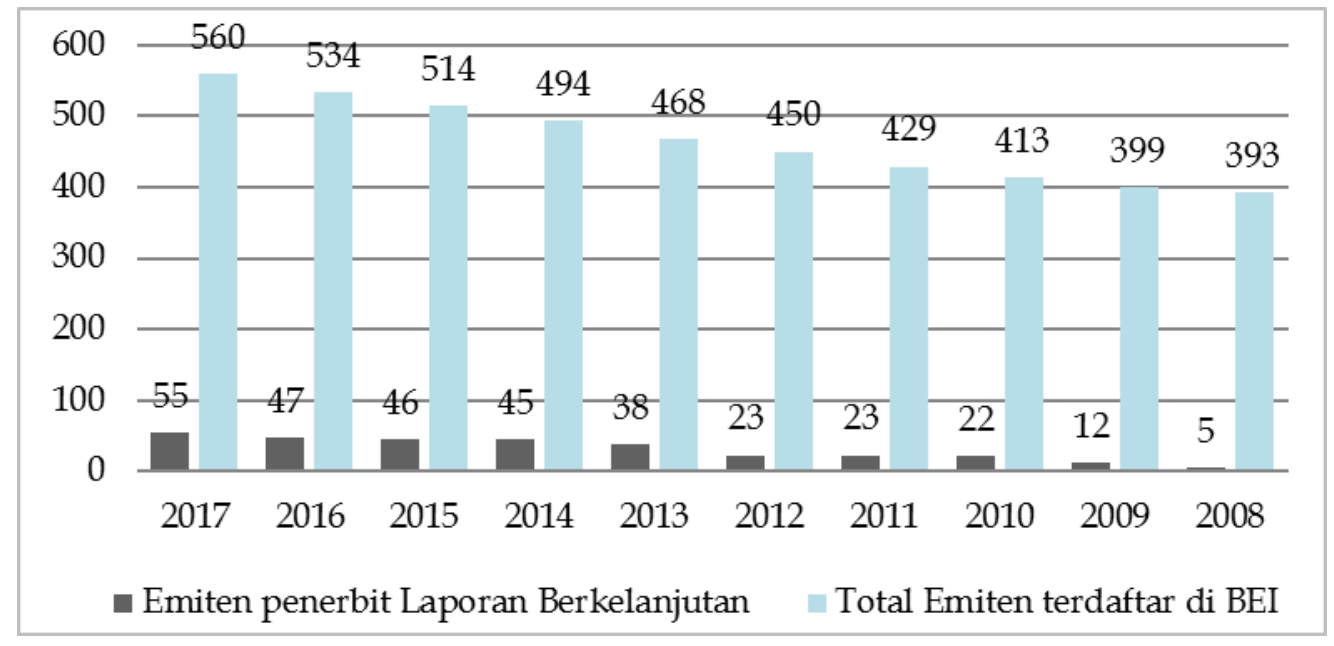

\section{Gambar 1.Grafik Jumlah Emiten Penerbit Laporan Berkelanjutan Sumber: Data diolah (2019)}

Kondisi masyarakat dan nilai nilai yang dianut masyarakat akan turut andil pada bentuk Tanggung Jawab Sosial Perusahaan. Indonesia merupakan salahsatu negara dengan penduduk terbesar di dunia mayoritas beragama Islam, sehingganilai nilai Islami menjadi salahsatu nilaiyang diterapkan dalam kehidupan sehari hari.Tanggung jawab sosial merupakan konsep yang sejalan dengan Agama Islam sejak 14 abad yang lalu. Agama Islam sangat mengingatkan kewajiban setiap orang untuk mempertanggung jawabkan segala perbuatannya kelak di hadapan Tuhan sang Pencipta Alam Semesta.Bentuk Tanggung Jawab Sosial Perusahaan yang bersumber dari nilai nilai Islami Al-Quran dan As-Sunnah dikenal dengan ICSR (Islamic Corporate Social Responsibility).Pengungkapan tanggung jawab sosial dalam suatu kerangka yang dapat mengakomodir kebutuhan ini dikenal dengan ISR (Islamic Social Reporting). Pengungkapan ISR menekankan padatransaksi yang sesuai dengan Al-Quran dan Hadits 
Reistiawati Utami dan Meina Wulansari Yusniar : Pengungkapan Islamic Corporate Social Responsibility (ICSR) dan Good Corporate Governance (GCG) terhadap Nilai Perusahaan dengan Kinerja Keuangan sebagai Variabel Intervening

termasuk pengungkapan transaksi perusahaan terkait dengan transaksi yang telah bebas dari unsur riba, spekulasi dan gharar, pengungkapan zakat, status kepatuhan syariah dan aspek sosial seperti assodaqoh, waqof, qordulhasan hingga pengungkapan ibadah di lingkungan perusahaan (Nahar, Chariri, \& Jatmiko, 2017).

Internal Perusahaan merupakan ruang lingkup yang terdekat dengan perusahaan dapat menjadi tahap awal dimulainya Tanggung jawab sosial perusahaan.Perusahaan dapat menjalankan kegiatan usaha sesuai dengan prinsip etika bisnis dan tuntutan para Pemangku Kepentingan. Konsep mengelola perusahaan dengan tata cara, sistem dan mekanisme yang mendukung terciptanya praktik bisnis yang baik dikenal dengan Good Corporate Governance (GCG). GCG mencakup juga didalamnya bentuk perlindungan tehadap kepentingan pemegang saham (Jallo, Mus, Mursalim, \& Suryanti, 2017).Pertumbuhan dan kesuksesan organisasi turut ditentukan oleh tanggung jawab sosial dan etika bisnis, karena dengan bertanggung jawab secara sosial maka korporasi akan memperoleh manfaat yaitu dengan membaiknya reputasi perusahaan, meningkatnya loyalitas pelanggan dan komunitas yang semakin kuat (Adda, Azigwe, \& Awuni, 2016). Indikatorkesuksesan organisasi dapat dilihat dari peningkatanProfitabilitas dan Nilai Perusahaan yang merupakan persepsi Investor tentang kesuksesan sebuah perusahaan.

Penelitian ini bertujuan untuk menganalisa pengaruh pengungkapan Tanggung Jawab Sosial Perusahaan khususnya Islamic Corporate Social Responsibility dan Good Corporate Governance pada perusahaan yang masuk pada JII Periode Tahun 2016 - 2018 terhadap Kinerja keuangan perusahaan dan terhadap Nilai Perusahaan. Penelitian ini juga menganalisa bentuk hubungan antara ICSR dan GCG terhadap Nilai Perusahaan secara langsung maupun tidak langsung melalui mediasi Kinerja Keuangan Perusahaan.

\section{KAJIAN PUSTAKA}

\section{Teori Legitimasi}

Teori Legitimasi merupakan teori yang menjelaskan adanya interaksi antara perusahaan dengan masyarakat. Teori Legitimasi menegaskan bahwa perusahaan harus melakukan upaya untuk memastikan bahwa aktifitas perusahaan dapat diterima atau dilegitimasi oleh pihak luar dengan beroperasi dalam bingkai dan norma yang ada dalam masyarakat atau lingkungan dimana perusahaan berada (Deegan, 2004).

Bentuk legitimasi mungkin akan mengalami perubahan seiring terjadinya pergeseran nilai nilai pada masyarakat dan lingkungan sehingga perusahaan dapat melakukan penyesuaian terhadap perubahan tersebut. Tanggung jawab sosial perusahaan adalah komitmen untuk berkontribusi pada pembangunan ekonomi berkelanjutan, hal ini merupakan upaya perusahaan untuk memperoleh legitimasi dari para stake holder.

\section{Teori Stake holder}

Stanford Research Institute (SRI) memperkenalkan istilah "stake holder" yakni merujuk kepada "those groups without whose support the organization would cease to exist" yang dapat diartikan merupakan kelompok kelompok yang tanpa dukungan dari mereka 
Reistiawati Utami dan Meina Wulansari Yusniar : Pengungkapan Islamic Corporate Social Responsibility (ICSR) dan Good Corporate Governance (GCG) terhadap Nilai Perusahaan dengan Kinerja Keuangan sebagai Variabel Intervening

suatu organisasi akan kehilangan keberadaanya (Freeman \& Reed, 1983). Menurut Teori Stake holder tujuan perusahaan didirikan bukan hanya untuk mencapai keuntungan yang diharapkan dan memenuhi kepentingannya sendiri, selain tujuan tersebut perusahaan harus dapat memberikan manfaat bagi para stake holder nya. Teori stake holder sepenuhnya konsisten dengan maksimasi nilai atau perilaku pencarian nilai, yang menyiratkan bahwa manajer harus memperhatikan semua konstituen sehingga dapat mempengaruhi nilai perusahaan (Jensen M. C., 2001).

\section{Teori Agency (Keagenan)}

Kontrak antara pemegang saham dan manajemen mendasari muculnya teori Keagenan. Menurut teori Agensi (Jensen \& Meckling, 1976), hubungan antara Pemilik Modal (Prinsipal) dan Manager (Agent) didefinisikan sebagai suatu kontrak dimana Principal memberikan wewenang kepada Agent untuk memaksimalkan manfaat Aset dan membuat keputusan yang berpihak kepada kepentingan Pemegang Saham. Bentuk hubungan ini dapat mengarah pada konflik kepentingan antara Principal dan Agent. Manajer biasanya akan memanfaatkan asimetri informasi yang terjadi karena pemisahan kekuatan ini, untuk kepentingannya sendiri (Samsi, Mustafa, \& Pontoh, 2014). Teori agensi memerlukan mekanisme pemantauan, karena sulit untuk percaya bahwa manajemen (agent) akan selalu bertindak untuk kepentingan pemegang saham (principal)(Weston \& Copeland, 1995). Konflik ini dapat dikurangi dengan suatu mekanisme pengawasan yang dapat melindungi kepentingan-kepentingan tersebut melalui penerapan GCG.

\section{Teori Signaling}

Teori Pensinyalan membahas bagaimana perusahaan menyampaikan informasi kepada pihak eksternal tentang kegiatan yang dilakukan dan kondisi yang dialami oleh pihak internal. Praktik pengungkapan berkelanjutan memberi sinyal kepada para pemangku kepentingan dan masyarakat tentang bagaimana perusahaan menata, mengelola dan menjaga dengan baik stabilitas keuangan, strategi lingkungan yang proaktif, implementasi CSR, komitmen perubahan iklim, dan keterlibatan pemangku kepentingan secara keseluruhan (Bae, Masud, \& Kim, 2018).

\section{HIPOTESIS}

\section{ICSR terhadap Kinerja Keuangan Perusahaan}

Teori Legitimasi menyebutkan, Perusahaan memiliki kontrak sosial dengan masyarakat berdasarkan nilai nilai keadilan dan norma sosial yang dianut oleh masyarakat sekitarnya. ICSR dapat mewakili sebagian besar nilai nilai yang dianut oleh masyarakat Indonesia mengingat Indonesia merupakan salahsatu negara dengan penduduk terbesar di dunia mayoritas beragama Islam.ICSR dapat menimbulkan kepercayaan konsumen yang selanjutnya dapat meningkatkan volume penjualan dan profitabilitas perusahaan.

Secara empiris penelitian yang memberikan bukti adanya pengaruh yang positif antara CSR terhadap Kinerja Perusahaan dilakukan oleh Jallo, Mus, Mursalim, \& Suryanti 
Reistiawati Utami dan Meina Wulansari Yusniar : Pengungkapan Islamic Corporate Social Responsibility (ICSR) dan Good Corporate Governance (GCG) terhadap Nilai Perusahaan dengan Kinerja Keuangan sebagai Variabel Intervening

(2017), Ilmi, Kustono, \& Sayekti (2017), Maryanti \& Fithri (2017) dan Firdaus, BZ, \& Diantimala (2018).

H1 : Kinerja Keuangan Perusahaan dipengaruhi secara positif oleh ICSR.

\section{ICSR terhadap Nilai Perusahaan}

Tanggung jawab sosial perusahaan merupakan cara perusahaan untuk dapat menjaga hubungan baik secara jangka panjang dengan para stake holdernya. ICSR dapat memberikan nilai lebih atas nilai saham perusahaan, khususnya di mata para Investor muslimyang memiliki kebutuhan untuk berinvestasi pada produk syariah. Kondisi demikian akan meningkatkan transaksi saham syariah dan pada akhirnya dapat meningkatkan Nilai Perusahaan.

Secara empiris Kurniasari, Wibowo, \& Wijaya (2017) dan Setiawan, Swandari, \& Dewi (2018) menghasilkan penelitian yang memberikan bukti bahwa Nilai Perusahaan dipengaruhi secara positif oleh CSR.

H2 : Nilai Perusahaan dipengaruhi secara positif oleh ICSR.

\section{GCG terhadap Kinerja Keuangan Perusahaan}

GCG dilandasi dengan teori Agensi yang menyebutkan bahwa hubungan antara pemilik modal (Principal) dan Manajemen Perusahaan (Agent) rentan terjadinya konflik kepentingan.Principal dapat mengendalikan hal ini dengan mengeluarkan biaya pemantauan yang dirancang membatasi aktivitas menyimpang dari Agent (Jensen \& Meckling, 1976). GCG terdiri dari perangkat dan sistem yang dibuat untuk mengendalikan dan mengawasi jalannya perusahaan.Manajemen akan didorong untuk menjalankan tugasnya sesuai dengan pedoman GCG sehingga perusahaan dapat mencapai kinerja terbaik.Kinerja keuangan secara positif dipengaruhi oleh GCG didukung penelitian oleh Jallo, Mus, Mursalim, \& Suryanti (2017), Ilmi, Kustono, \& Sayekti (2017), Firdaus, BZ, \& Diantimala (2018) danMai (2017).

H3 : Kinerja Perusahaan dipengaruhi secara positif oleh GCG.

\section{GCG terhadap Nilai Perusahaan}

Prinsip tranparansi, akuntabilitas, responsibility, independen dan kewajaran dalam GCG akan membantu meningkatkan kepercayaan para Investor terhadap perusahaan sehingga akan tergerak untuk berinvestasi pada perusahaan dengan penerapan GCG. Semakin baik penerapan GCG maka akan semakin besar kepercayaan investor.

Penelitian yang dilakukan oleh Jallo, Mus, Mursalim, \& Suryanti (2017), Ilmi, Kustono, \& Sayekti (2017) dan Firdaus, BZ, \& Diantimala (2018) memberikan hasil adanya pengaruh positif antara GCG dan Nilai Perusahaan.

H4 : Nilai Perusahaan dipengaruhi secara positif oleh GCG.

\section{Kinerja Keuangan terhadap Nilai Perusahaan}

Nilai perusahaan terkait dengan kemakmuran pemilik atau pemegang saham serta indentik dengan harga saham. Semakin tinggi harga saham maka kemakmuran Investor akan semakin meningkat. Nilai Perusahaan dapat diukur dari kemampuan perusahaan dalam mengelola asset nya sehingga mampu menghasilkan laba. Laba perusahaan akan didistribusikan kepada pemilik saham dalam bentuk dividen atau diinvestasikan kembali 
Reistiawati Utami dan Meina Wulansari Yusniar : Pengungkapan Islamic Corporate Social Responsibility (ICSR) dan Good Corporate Governance (GCG) terhadap Nilai Perusahaan dengan Kinerja Keuangan sebagai Variabel Intervening

untuk memperkuat atau memperbesar bisnis perusahaan. Semakin baik respon investor akan tercermin pada kenaikan harga saham yang juga berarti Nilai Perusahaan semakin meningkat.

Penelitian untuk menguji Nilai Perusahaan yang dipengaruhi secara positif oleh kinerja keuangan dibuktikan oleh Sutapa \& Laksito (2018), Jallo, Mus, Mursalim, \& Suryanti (2017), Ilmi, Kustono, \& Sayekti (2017), Nahar, Chariri, \& Jatmiko (2017), Mai(2017) dan Firdaus, BZ, \& Diantimala (2018).

H5 : Nilai Perusahaan dipengaruhi secara positif oleh GCG.

\section{Nilai Perusahaan dipengaruhi oleh ICSR dengan mediasi Kinerja Keuangan}

Hubungan tidak langsung pengaruh ICSR terhadap Nilai Perusahaan diperoleh melalui reputasi perusahaan yang dapat menimbulkan kepercayaan para stake holder. Reputasi yang baik akan menarik perhatian konsumen, menghasilkan kepuasan pelanggan, menciptakan loyalitas konsumen sehingga dapat meningkatkan pendapatan dan keuntungan perusahaan. Keuntungan perusahaan merupakan suatu daya tarik untuk investasi dan dapat meningkatkan Nilai perusahaan.

Penelitian untuk menguji Nilai Perusahaan dipengaruhi secara positif oleh Tanggung jawab sosial perusahaan dimediasi oleh kinerja keuangan ditemukan pada penelitian Firdaus, BZ, \& Diantimala (2018), Jallo, Mus, Mursalim, \& Suryanti(2017), Maryanti \& Fithri (2017), dan Santoso (2017).

H6 : Nilai Perusahaan dipengaruhi secara positif oleh ICSR dengan dimediasi oleh kinerja keuangan.

\section{Nilai Perusahaan dipengaruhi oleh GCG dengan mediasi Kinerja Keuangan}

Secara tidak langsung GCG berpengaruh terhadap Nilai Perusahaan dengan cara mendorong perusahaan untuk bertindak secara profesional disertai pengawasan dan pengendalian yang memadai. GCG akan membawa perusahaan mencapai kinerja terbaik untuk menghasilkan profit. Perusahaan dengan pertumbuhan profit yang baik akan menjadi daya tarik para Investor sehingga akan mengundang Investasi yang lebih banyak dan pada akhirnya akan meningkatkan Nilai Perusahaan.

Penelitian untuk menguji Nilai Perusahaan dipengaruhi secara positif oleh GCG dengan Kinerja keuangan sebagai variabel yang dapat menjadi mediasi ditemukan pada penelitian Firdaus, BZ, \& Diantimala(2018), Jallo, Mus, Mursalim, \& Suryanti(2017), Maryanti \& Fithri (2017), Santoso(2017).

H7 : Nilai Perusahaan dipengaruhi secara positif oleh GCG dengan dimediasi oleh Kinerja Keuangan.

\section{METODE}

Penelitian ini menggunakan pendekatan kuantitatif dengan populasi perusahaan perusahaan terdaftar di Bursa Efek Indonesia (BEI) yang masuk dalam Jakarta Islamic Index (JII) selama periode Tahun 2016 - 2018. Sampel dipilih dengan teknik purposive sampling menggunakan kriteria :

1. Perusahaan yang masuk dalam JII selama periode Tahun 2016 - 2018. 
Reistiawati Utami dan Meina Wulansari Yusniar : Pengungkapan Islamic Corporate Social Responsibility (ICSR) dan Good Corporate Governance (GCG) terhadap Nilai Perusahaan dengan Kinerja Keuangan sebagai Variabel Intervening

2. Perusahaan yang secara konsisten berada dalam JII selama periode Tahun 2016 - 2018.

3. Perusahaan yang memiliki Laporan Tahunan yang lengkap selama Periode tahun 2016 - 2018.

Perusahaan yang masuk dalam kriteria adalah sebanyak 17 Perusahaan sebanyak 51 pengamatan selama periode Tahun 2016 - 2018. Data yang digunakan dalam penelitian ini merupakan data sekunder berupa Laporan Tahunan Perusahaan yang diunduh melalui situs www.idx.co.id, kemudian diolah menjadi Index banyaknya pengungkapan dan rasio keuangan.

\section{Definisi Operasional Variabel}

Variabel Independen terdiri dari ICSR (Islamic Corporate Social Responsibility) dan GCG (Good Corporate Governance).

1. ICSR adalah pengungkapan Tanggung jawab Sosial Islami Perusahaan yang diukur menggunakan Index ISR (Islamic Social Reporting).ISR berisi kompilasi item-item standar tanggung jawab sosial perusahaan yang ditetapkan oleh AAOIFI (Accounting and Auditing Organization for Islamic Financial Institutions). ISR terdiri 43 butir standar ICSR dibagi dalam 5 aspek yaitu Pembiayaan dan Investasi, Produk dan jasa, Karyawan, Masyarakat, Lingkungan dan Tata Kelola.

2. GCG adalah bentuk Tata Kelola Perusahaan yang baik, yang dikur dengan banyaknya pengungkapan kepatuhan GCG berupa Index GCG bersumber dari Pedoman KNKG (2006) dan Peraturan OJK No. 21/POJK.04/2015 tentang Penerapan Pedoman Tata Kelola Perusahaan Terbuka. Terdapat 20 item yang disadur dari Pedoman KNKG (2006) dan 25 item pengungkapan Implementasi GCG oleh perusahaan terbuka yang diwajibkan OJK sehingga total sebanyak 45 item pengungkapan GCG.

Setiap pengungkapan dalam indeks diberi nilai 1 jika memenuhi, dan 0 jika tidak memenuhi. Skor Index diperoleh dengan membandingkan banyaknya pengungkapan dalam Laporan Tahunan dibagi dengan total pengungkapan yang diharapkan dengan rumus sebagai berikut :

$$
\text { Indeks }=\frac{\text { Jumlah item yang diungkapkan }}{\text { Jumlah item yang diharapkan }}
$$

Variabel Dependen yaitu Nilai Perusahaan merupakan persepsi investor terhadap tingkat keberhasilan perusahaan yang tercermin pada harga saham (Brigham \& Daves, 2010). Nilai Perusahaan diukur menggunakan PBV (Price to Book Value). PBV merupakan perbandingan antara harga pasar per lembar saham dengan nilai buku per lembar saham. PBV diatas 1 menunjukkan harga saham telah melebihi Nilai Bukunya, artinya pasar memberikan nilai lebih terhadap saham yang juga berarti Investor memiliki ekspektasi lebih terhadap tingkat keberhasilan perusahaan.

$$
\mathrm{PBV}=\frac{\text { Harga Pasar saham per lembar saham }}{\text { Nilai buku modal saham per lembar saham }}
$$


Reistiawati Utami dan Meina Wulansari Yusniar : Pengungkapan Islamic Corporate Social Responsibility (ICSR) dan Good Corporate Governance (GCG) terhadap Nilai Perusahaan dengan Kinerja Keuangan sebagai Variabel Intervening

Variabel Intervening yakni Kinerja Perusahaan (Profitabilitas) merupakan kemampuan perusahaan untuk menghasilkan keuntungan pada periode tertentu (Brigham \& Houston, 2006). Profitabilitas diukur dengan rasio ROE, yaitu perbandingan antara laba perusahaan dengan ekuitas perusahaan pada akhir periode laporan keuangan perusahaan.

\section{$\mathrm{ROE}=\frac{\text { Laba Bersih }}{\text { Modal Saham }}$}

\section{Analisa Data}

Pengujian pengaruh langsung maupun tidak langsung antara Variabel Independen terhadap Variabel Intervening dan Variabel Dependen mengggunakan uji Regresi Berganda dengan analisis jalur. Alat Analisis yang digunakan adalah Partial Least Square (PLS) dengan software Smart PLS 3.0. PLS merupakan bagian dari Structural Equation Model dengan basis varian yang didesain untuk menyelesaikan regresi berganda ketika terjadi permasalahan spesifik pada data seperti ukuran sampel penelitian kecil, adanya data yang hilang dan mengabaikan efek multikolinearitas antar indikator dan variabel laten (Hartono \& Abdillah, 2016). PLS dapat dijalankan pada data yang tidak berdistribusi normal dan perkiraan parameter langsung dapat dilakukan karena tidak memerlukan terpenuhinya kriteria goodnes of fit (Ghozali \& Latan, 2015).

\section{HASIL DAN PEMBAHASAN}

Analisis pola hubungan antar variabel untuk menentukan pengaruh langsung atau langsung dari variabel Independen terhadap Variabel Dependen menggunakan analisis jalur. Melalui analisis jalur dapat diketahui bentuk hubungan antar variabel beserta jalur dan kekuatan hubungan antar variabel. Model analisis jalur ditunjukkan pada Gambar 2 berikut.

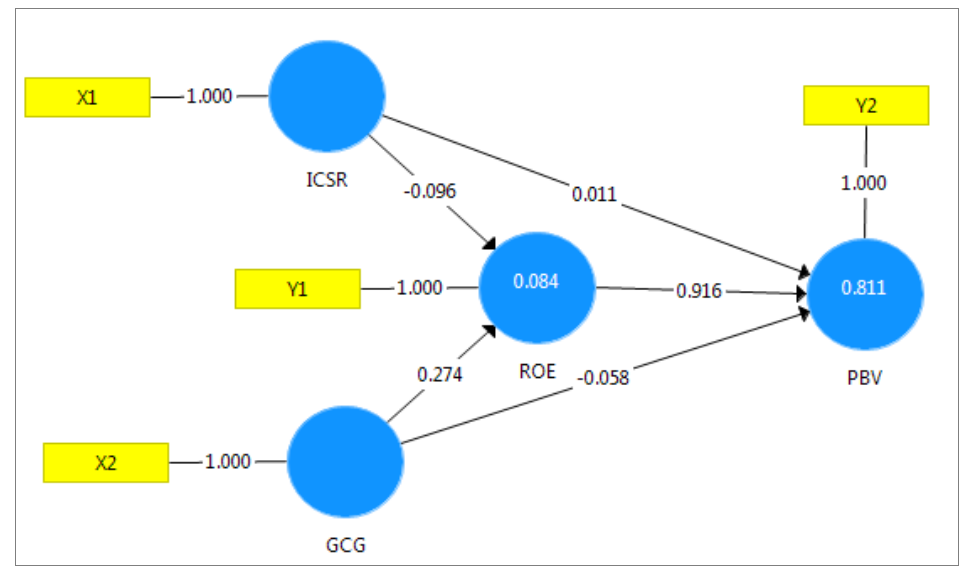

Gambar 2.Analisis Jalur

Sumber: Output PLS 3.0 (2019)

Uji Hipotesis dilihat dari nilai signifikansi dari hubungan antar variabel dan koefisien hubungan pengaruh variabel independen terhadap variabel dependen. Hasil pengujian analisis jalur menunjukkan signifikansi antar variabel dalam penelitian. Koefisien jalur menunjukkan arah dan seberapa besar pengaruh Variabel Independen 
Reistiawati Utami dan Meina Wulansari Yusniar : Pengungkapan Islamic Corporate Social Responsibility (ICSR) dan Good Corporate Governance (GCG) terhadap Nilai Perusahaan dengan Kinerja Keuangan sebagai Variabel Intervening

terhadap Variabel Endogen. Signifikansi model dapat dilihat dengan membandingkan nilai $\mathrm{t}$-values dengan t-hitung yang dalam model intervening menggunakan $\mathrm{t}$ hitung sebesar 1,96.Hasil tes hipotesis untuk menguji pengaruh langsung dijelaskan dalam Tabel 1 berikut :

Tabel 1. Koefisien Jalur dan t-value untuk Pengaruh Langsung

\begin{tabular}{lccccc}
\hline & $\begin{array}{c}\text { Original } \\
\text { Sample (0) }\end{array}$ & $\begin{array}{c}\text { Sample } \\
\text { Mean }(M)\end{array}$ & $\begin{array}{c}\text { Standard } \\
\text { Deviation } \\
(\text { STDEV })\end{array}$ & $\begin{array}{c}\text { T Statistic } \\
(|0 / S T D E V|)\end{array}$ & $\begin{array}{c}\text { Values } \\
\text { ICSR-> ROE }\end{array}$ \\
\hline ICSR -> PBV & $-0,096$ & $-0,099$ & 0,122 & 0,788 & 0,431 \\
\hline GCG -> ROE & 0,274 & $-0,101$ & 0,122 & 0,633 & 0,527 \\
\hline GCG -> PBV & 0,193 & 0,276 & 0,063 & 4,359 & 0,000 \\
\hline ROE -> PBV & 0,916 & 0,192 & 0,062 & 3,104 & 0,002 \\
\hline
\end{tabular}

\section{Sumber: Output PLS 3.0 (2019)}

1. Koefisien jalur ICSR terhadap ROE memiliki nilai sebesar -0,096, menunjukkan adanya pengaruh negatif dari ICSR terhadap ROE. Nilai t-statistic $<1,96$ atau 0,788 $<1,96$ berarti bahwa ICSR berpengaruh negatif tidak signifikan terhadap ROE, sehingga hipotesis penelitian (H1) Kinerja Keuangan Perusahaan dipengaruhi secara positif oleh ICSR ditolak.

Hasil ini tidak mendukung penelitian Arifin \& Wardani (2016), Jallo, Mus, Mursalim, \& Suryanti(2017) dan Ilmi, Kustono, \& Sayekti (2017). ICSR merupakan bentuk tanggung jawab sosial perusahaan yang lebih spesifik dalam mengimplementasikan nilai nilai Islami dalam menjalankan kegiatan usaha perusahaan. Filosofi ICSR lebih bersifat holistik dan merupakan pertanggungjawaban utama dan langsung secara vertikal terhadap Sang Pencipta Allah SWT. Berdasarkan hasil index ISR, ICSR belum diterapkan secara maksimal pada perusahaan yang masuk dalam JII periode tahun 2016 - 2018. Penerapan ICSR dalam perusahaan dapat dianggap sebagai tambahan biaya sehingga dapat mengurangi keuntungan perusahaan.

2. Koefisien jalur ICSR terhadap PBV memiliki nilai sebesar $-0,077$, menunjukkan adanya pengaruh negatif dari ICSR terhadap PBV. Nilai t-statistic $<1,96$ atau 0,633 < 1,96 berarti bahwa ICSR berpengaruh negatif tidak signifikan terhadap PBV, sehingga hipotesis penelitian (H2) Nilai Perusahaan dipengaruhi secara positif oleh ICSR ditolak.

Hasil tersebut tidak mendukung penelitian Kurniasari, Wibowo, \& Wijaya(2017), namun mendukung penelitian yang dilakukan oleh Jallo, Mus, Mursalim, \& Suryanti (2017), Firdaus, BZ, \& Diantimala(2018), Ilmi, Kustono, \& Sayekti, (2017), dan Sutapa \& Laksito(2018). Persepsi para Investor akan ikut mempengaruhi Nilai Perusahaan. Mayoritas Pemilik Modal dari Perusahaan perusahaan yang masuk pada JII periode 2016 - 2018 dimiliki oleh Holding Company, Penanaman Modal Asing, dan Pemerintah Indonesia dimana persepsi CSR mereka masih bersifat umum mengikuti 
Reistiawati Utami dan Meina Wulansari Yusniar : Pengungkapan Islamic Corporate Social Responsibility (ICSR) dan Good Corporate Governance (GCG) terhadap Nilai Perusahaan dengan Kinerja Keuangan sebagai Variabel Intervening

bentuk CSR yang berakar dari dunia barat sehingga penerapan ICSR justru memberikan pengaruh negatif terhadap Nilai Perusahaan.

3. Koefisien jalur GCG terhadap ROE memiliki nilai sebesar 0,274 menunjukkan adanya pengaruh positif dari GCG terhadap ROE. Nilai t-statistic $>1,96$ atau 4,359 > 1,96 berarti bahwa GCG berpengaruh positif signifikan terhadap ROE, sehingga hipotesis penelitian (H3) Kinerja Perusahaan dipengaruhi secara positif oleh GCG diterima.

Hal tersebut mendukung penelitian Santoso A. (2017), Jallo, Mus, Mursalim, \& Suryanti(2017), Ilmi, Kustono, \& Sayekti(2017), Firdaus, BZ, \& Diantimala(2018) dan Mai (2017). Mekanisme GCG yang dirancang untuk mengatur dan mengendalikan Perusahaan untuk menjalankan Perusahaan dengan baik dapat mendorong perusahaan menuju pertumbuhan dan kinerja keuangan yang positif.

4. Koefisien jalur GCG terhadap PBV memiliki nilai sebesar 0,193 menunjukkan adanya pengaruh positif dari GCG terhadap PBV. Nilai t-statistic $>1,96$ atau 3,104 $>1,96$ berarti bahwa GCG berpengaruh positif signifikan terhadap PBV, sehingga hipotesis penelitian (H4) Nilai Perusahaan dipengaruhi secara positif oleh GCG diterima.

Hasil tersebut mendukung penelitian Jallo, Mus, Mursalim, \& Suryanti, (2017), Ilmi, Kustono, \& Sayekti (2017) dan Firdaus, BZ, \& Diantimala(2018). Praktik GCG pada perusahaan dapat menimbulkan kepercayaan para Investor bahwa perusahaan dapat mengelola investasi mereka dengan baik. Sistem dan mekanisme pengendalian dan pengawasan dalam perusahaan dapat melindungi kepentingan para stake holder khususnya pemilik modal / Investor.

5. Koefisien jalur ROE terhadap PBV memiliki nilai sebesar 0,916 menunjukkan adanya pengaruh positif dari ROE terhadap PBV. Nilai t-statistic $>1,96$ atau 29,914 $>1,96$ berarti bahwa ROE berpengaruh positif signifikan terhadap PBV, sehingga hipotesis penelitian (H5) Nilai Perusahaan dipengaruhi secara positif oleh Kinerja Keuangan diterima.

Hasil tersebut mendukung penelitian Sutapa \& Laksito(2018), Jallo, Mus, Mursalim, \& Suryanti (2017), (Ilmi, Kustono, \& Sayekti(2017), Nahar, Chariri, \& Jatmiko(2017), Mai(2017) dan Firdaus, BZ, \& Diantimala(2018). Profitabilitas merupakan daya tarik bagi para Investor. Profitabilitas menunjukkan kemampuan perusahaan dalam mengelola asset perusahaan. Profitabilitas yang tinggi juga merupakan salahsatu prediktor pembagian dividen kepada pemegang saham. Semakin baik kemampuan perusahaan mempertahankan dan meningkatkan laba maka akan menarik minat Investor yang kemudian dapat meningkatkan Nilai Perusahaan.

Hasil pengaruh tidak langsung dapat diperoleh dari hasil perkalian koefisian jalur variabel eksogen terhadap variabel intervening dengan koefisien jalur variabel intervening terhadap variabel endogen. Pengaruh total dapat diketahui dengan cara menjumlahkan nilai koefisien pengaruh langsung dengan hasil kali nilai koefisien pengaruh tidak langsung. Perhitungan Koefisien jalur dan t-value untuk pengaruh tidak langsung dapat dilihat pada tabel Tabel 2. 
Reistiawati Utami dan Meina Wulansari Yusniar : Pengungkapan Islamic Corporate Social Responsibility (ICSR) dan Good Corporate Governance (GCG) terhadap Nilai Perusahaan dengan Kinerja Keuangan sebagai Variabel Intervening

Tabel 2. Koefisien Jalur dan t-value untuk Pengaruh Tidak Langsung

\begin{tabular}{lccccc}
\hline & $\begin{array}{c}\text { Original } \\
\text { Sample (0) }\end{array}$ & $\begin{array}{c}\text { Sample } \\
\text { Mean } \\
(M)\end{array}$ & $\begin{array}{c}\text { Standard } \\
\text { Deviation } \\
(\text { STDEV })\end{array}$ & $\begin{array}{c}\text { T Statistic } \\
(\mid 0 / \text { STDEV } \mid)\end{array}$ & $\begin{array}{c}P \\
\text { Values }\end{array}$ \\
\hline ICSR-> ROE-> PBV & $-0,088$ & $-0,094$ & 0,115 & 0,766 & 0,444 \\
\hline GCG -> ROE-> PBV & 0,251 & 0,257 & 0,059 & 4,221 & 0,000 \\
\hline
\end{tabular}

Sumber: Output PLS 3.0 (2019)

Pengaruh antar variabel secara langsung,tidak langsung dan secara total dapat dilihat pada tabel Tabel 3.

Tabel 3. Total Pengaruh Langsung dan Tidak Langsung

\begin{tabular}{|c|c|c|c|c|c|c|c|}
\hline \multicolumn{3}{|c|}{ Variabel } & \multicolumn{3}{|c|}{ Pengaruh } & \multirow[b]{2}{*}{$\begin{array}{c}\text { T Statistic } \\
(|0 / S T D E V|)\end{array}$} & \multirow[b]{2}{*}{$\begin{array}{c}P \\
\text { Values }\end{array}$} \\
\hline $\begin{array}{c}\text { Independ } \\
\text { en }\end{array}$ & Intervening & Dependen & Langsung & $\begin{array}{c}\text { Tidak } \\
\text { Langsung }\end{array}$ & Total & & \\
\hline ICSR & - & ROE & $-0,096$ & & & 0,788 & 0,431 \\
\hline ICSR & - & PBV & $-0,077$ & & & 0,633 & 0,527 \\
\hline GCG & 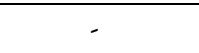 & ROE & 0,274 & & & 4,359 & 0,000 \\
\hline GCG & - & PBV & 0,193 & & & 3,104 & 0,002 \\
\hline ROE & 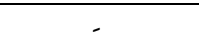 & PBV & 0,916 & & & 22,914 & 0,000 \\
\hline ICSR & ROE & PBV & $-0,077$ & $-0,088$ & $-0,165$ & 0,766 & 0,444 \\
\hline GCG & ROE & PBV & 0,193 & 0,251 & 0,444 & 4,221 & 0,000 \\
\hline
\end{tabular}

Sumber: Hasil Analisis (2019)

1. Koefisien jalur ICSR terhadap PBV melalui ROE memiliki nilai sebesar -0,088 yang diperoleh dari hasil perkalian -0,096 (koefisien jalur ICSR terhadap ROE) dengan 0,916 (koefisien jalur ROE terhadap PBV). Total pengaruh sebesar -0,165 diperoleh dari penjumlahan -0,077 (koefisien pengaruh langsung ICSR terhadap PBV) ditambah -088 (koefisien pengaruh tidak langsung ICSR terhadap PBV melalui ROE). Nilai t-statistik $<$ 1,96 atau 0,766 < 1,96 berarti bahwa ICSR berpengaruh negatif tidak signifikan terhadap Nilai Perusahaan yang dimediasi oleh Kinerja Keuangan, sehingga hipotesis penelitian (H6) Nilai Perusahaan dipengaruhi secara positif oleh ICSR dengan dimediasi oleh kinerja keuangan ditolak.

Hasil tersebut mendukung penelitian Jallo, Mus, Mursalim, \& Suryanti (2017).ICSR tidak memberikan kontribusi positif melalui Kinerja Keuangan dalam mempengaruhi Nilai Perusahaan. Hasil penelitian ini menunjukkan rata rata Index ICSR pada angka 0,541 sehingga dapat diartikan ICSR belum diaplikasikan dengan baik pada perusahaan yang masuk dalam JII periode 2016 - 2018 atau ICSR belum menjadi nilai nilai yang dominan pada masyarakat Indonesia sehingga ICSR belum berhasil mempengaruhi persepsi para stake holder.

2. Koefisien jalur GCG terhadap PBV melalui ROE memiliki nilai sebesar 0,251 yang diperoleh dari hasil perkalian 0,274 (koefisien jalur GCG terhadap ROE) dengan 0,916 (koefisien jalur ROE terhadap PBV). Total pengaruh sebesar 0,444 diperoleh dari penjumlahan 0,193 (koefisien pengaruh langsung GCG terhadap PBV) ditambah 0,251 (koefisien pengaruh tidak langsung GCG terhadap PBV melalui ROE). Nilai t-statistik 
Reistiawati Utami dan Meina Wulansari Yusniar : Pengungkapan Islamic Corporate Social Responsibility (ICSR) dan Good Corporate Governance (GCG) terhadap Nilai Perusahaan dengan Kinerja Keuangan sebagai Variabel Intervening

$>$ 1,96 atau 4,221 > 1,96 berarti bahwa GCG berpengaruh positif signifikan terhadap Nilai Perusahaan yang dimediasi oleh Kinerja Keuangan, sehingga hipotesis penelitian (H7) Nilai Perusahaan dipengaruhi secara positif oleh GCG dengan dimediasi oleh Kinerja Keuangan Perusahan diterima.

Hasil tersebut mendukung penelitian Maryanti \& Fithri (2017), Santoso A.(2017) dan Jallo, Mus, Mursalim, \& Suryanti(2017). GCG dapat mendorong manajemen untuk bekerja dengan profesional sehingga perusahan akan mencapai kinerja keuangan yang baik. Perusahaanan dengan kinerja keuangan yang baik dapat meningkatkan persepsi Investor terhadap Perusahaan yang ditunjukkan dengan meningkatnya Nilai Perusahaan. Manajemen dianggap mampu mengelola investasi dengan baik sehingga dapat meningkatkan kemakmuran pemegang saham.

Koefisien Determinasi $\left(\mathrm{R}^{2}\right)$ digunakan untuk mengukur tingkat variasi perubahan variabel independen terhadap variabel dependen. Hasil R²dapat dilihat padatabel Tabel 4 berikut :

Tabel 4. Hasil Perhitungan R Square $\left(\mathbf{R}^{2}\right)$

\begin{tabular}{lcc}
\hline & R Square & R Square Adjusted \\
\hline PBV & 0,811 & 0,799 \\
\hline ROE & 0,084 & 0,045
\end{tabular}

Sumber: Hasil Analisis (2019)

Hasil $\mathrm{R}^{2}$ pada Tabel 5.9. diketahui diketahui bahwa Variabel nilai perusahaan dapat dijelaskan oleh variabel Good Corporate Governance (GCG) dan Islamic Corporate Social Responsibility (ICSR), serta Profitabilitas sebesar 81 \% sisanya sebesar 19 \% merupakan variabel lain yang tidak terdapat dalam model penelitian. Profitabilitas dapat dijelaskan oleh Good Corporate Governance (GCG) dan Islamic Corporate Social Responsibility (ICSR) sebesar $8 \%$ sisanya sebesar $92 \%$ merupakan variabel lain yang tidak terdapat dalam model penelitian.

\section{KESIMPULAN}

Secara umum kesimpulan dari hasil penelitian ini adalah 1). ROE sebagai proksi Kinerja Keuangan Perusahaan tidak dipengaruhi oleh ISR sebagai proksi ICSR, 2). PBV sebagai proksi Nilai Perusahaan tidak dipengaruhi oleh ISR sebagai proksi ICSR, 3). ROE sebagai proksi Kinerja keuangan perusahaan dipengaruhi secara signifikan oleh GCG, 4). PBV sebagai proksi Nilai Perusahaan dipengaruhi secara signifikan oleh GCG, 5). PBV sebagai proksi Nilai Perusahaan dipengaruhi secara signifikan oleh ROE sebagai proksi Kinerja Keuangan Perusahaan, 6). ROE sebagai proksi Kinerja Keuangan Perusahaan tidak berhasil menjadi mediasi pengaruh ISR sebagai proksi ICSR, terhadap PBV sebagai Proksi Nilai Perusahaan, 7). Hubungan pengaruh tidak langsung antara GCG yang diukur dengan indeks GCG terhadap PBV sebagai proksi Nilai Perusahaan berhasil dimediasi oleh ROE sebagai proksi Kinerja Keuangan.

Penelitian ini memiliki keterbatasan berupa penggunaan data sekunder yang masih terikat pada pedoman yang telah ditetapkan sehingga belum dapat menggali 
Reistiawati Utami dan Meina Wulansari Yusniar : Pengungkapan Islamic Corporate Social Responsibility (ICSR) dan Good Corporate Governance (GCG) terhadap Nilai Perusahaan dengan Kinerja Keuangan sebagai Variabel Intervening

informasi yang diharapkan.Penelitian selanjutnya dapat menggunakan data primer sehingga dapat memperoleh informasi yang lebih akurat.

Pendekatan variabel dapat lebih dikembangkan dengan menggunakan konstruk atau indikator yang dapat mencerminkan pelaksanaan ICSR secara lebih baik

\section{DAFTAR PUSTAKA}

Adda, G., Azigwe, D. J., \& Awuni, A. R. (2016). Bussiness Ethics and Corporate Social Responsibility For Bussiness Success. European Journal of Business and Innovation Research Vol.4, .

Arifin, J., \& Wardani, E. A. (2016). Islamic corporate social responsibility disclosure, reputasi, dan kinerja keuangan: Studi pada bank syariah di Indonesia. Jurnal Akuntansi \& Auditing Indonesia 20(1) .

Bae, S. M., Masud, M. A., \& Kim, J. D. (2018). A Cross-Country Investigation of Corporate Governance and Corporate Sustainability Disclosure: A Signaling Theory Perspective. Sustainabilty Journal .

Brigham, E. F., \& Houston. (2006). Fundamental of FinancialManagement:Dasar-Dasar Manajemen Keuangan. Edisi 10. Jakarta: Salemba Empat.

Brigham, E., \& Daves, P. (2010). Intermediate Financial Management. Tenth Edition. South Western: Cengage Learning.

Deegan, C. (2004). Financial Accounting Theory. Sydney: McGraw-Hill.

Dusuki, A. W. (2008). What Does Islam Say about Corporate Social Responsibility? Review ofIslamic Economics, Vol. 12, NO.1, .

Firdaus, A., BZ, F. S., \& Diantimala, Y. (2018). The Influence of Good Corporate Governance and Corporate Social Responsibility towards the Financial Performance that has Implications for Firm Value of Banking Companies Listed in Indonesia Stock Exchange. Human Resource Management Academic Research Society .

Freeman, R. E., \& Reed, D. L. (1983). Stockholders Stock and stakeholders. California Management Review.

Ghozali, P. D., \& Latan, H. S. (2015). PARTIAL LEAST SQUARE Konsep, Teknik dan Aplikasi menggunakan Program Smart PLS 3.0. Semarang: Badan Penerbit - Undip.

Governance, K. N. (2006). Pedoman Umum Good Corporate Governance Indonesia. Pedoman Umum Good Corporate Governance Indonesia . Jakarta: Komite Nasional Kebijakan Governance.

Hanafi, M. M. (2014). Manajemen Keuangan. Edisi 1. Yogyakarta: BPFE. 
Reistiawati Utami dan Meina Wulansari Yusniar : Pengungkapan Islamic Corporate Social Responsibility (ICSR) dan Good Corporate Governance (GCG) terhadap Nilai Perusahaan dengan Kinerja Keuangan sebagai Variabel Intervening

Haniffa, R. (2002). Social Reporting Disclosure : An Islamic Perspective. Indonesian Management \& Accounting Research Vol 1 No 2.

Hartono, J., \& Abdillah, W. (2016). Konsep \& Aplikasi PLS (Partial Least Square) untuk Penelitian Empiris. Yogyakarta: BPFE.

Ilmi, M., Kustono, A. S., \& Sayekti, Y. (2017). Effect Of Good Corporate Governance, Corporate Social Responsibility Disclosure Aand Managerial Ownership To The Corporate Value With Financial Performance As Intervening Variables: Case On Indonesia Stock Exchange. International Journal of Social Science and Business .

Jallo, A., Mus, A. R., Mursalim, \& Suryanti. (2017). Effect of corporate social responsibility, good corporate governance and ownership structure on financial performance and firm value: A Study in Jakarta Islamic Index. IOSR Journal of Business and Management (IOSR-JBM) .

Jensen, M. C. (2001). Value Maximization, Stakeholder Theory, and the Corporate Objective Function. JOURNAL OF APPLIED CORPORATE FINANCE .

Jensen, M. C., \& Meckling, W. H. (1976). THEORY OF THE FIRM: MANAGERIAL BEHAVIOR, AGENCY COSTS AND OWNERSHIP STRUCTURE. Journal of Financial Economics 3 .

Kurniasari, W., Wibowo, B. J., \& Wijaya, Y. A. (2017). The Mediating Effect of Corporate Social Responsibility and Good Corporate Governance on the Company's Firm Value. Research Journal of Social Sciences .

Mai, M. U. (2017). Mediation of CSR and Profitability on The Influences of GCG Mechanism to The Firm Value. Jurnal Keuangan dan Perbankan .

Maryanti, E., \& Fithri, W. N. (2017). Corporate Social Responsibilty, Good Corporate Governance, Kinerja Lingkungan Terhadap Kinerja Keuangan Dan Pengaruhnya Pada Nilai Perusahaan. Journal Of Accounting Science Vol. 1 No. 1 EISSN 2548-3501 .

Nahar, A., Chariri, A., \& Jatmiko, T. (2017). Islamic social report, good corporate governance financial performance and company value. The 2nd International Conference on Accounting, Business \& Economics. Yogyakarta: Faculty of Economics, Unversitas Islam Indonesia.

Othman, R., \& Thani, A. M. (2010). Islamic Social Reporting Of Listed Companies In Malaysia. International Business \& Economics Research Journal.

Samsi, H., Mustafa, M., \& Pontoh, G. T. (2014). The effect of corporate governance on the relationship between corporate social responsibility disclosure and corporate value. The Indonesian Accounting Review Vol. 4, No. 1 .

Santoso, A. (2017). Pengaruh Good Corporate Governance terhadap Nilai Perusahaan dengan Kinerja Keuangan sebagai Variabel Intervening. SNAPER-EBIS. 
Reistiawati Utami dan Meina Wulansari Yusniar : Pengungkapan Islamic Corporate Social Responsibility (ICSR) dan Good Corporate Governance (GCG) terhadap Nilai Perusahaan dengan Kinerja Keuangan sebagai Variabel Intervening

Setiawan, I., Swandari, F., \& Dewi, D. M. (2018). Pengaruh Pengungkapan Islamic Social Reporting (ISR) Terhadap Nilai Perusahaan Dengan Kinerja Keuangan Sebagai Variabel Moderating. Jurnal Wawasan Manajemen .

Sutapa, \& Laksito, H. (2018). Peran Islamic Social Reporting terhadap Nilai Perusahaan. Jurnal Akuntansi Indonesia, Vol. 7 No. 1 .

Weningtyas, N., \& Yusniar, M. W. (2013). Penyusunan Indeks Tata Kelola Perbankan dan Pengaruhnya Terhadap Kinerja Perbankan Indonesia. Banjarmasin. Prosiding SNA XVII. Mataram.

Weston, J. F., \& Copeland, T. E. (1995). Manajemen Keuangan. Edisi 9, Jilid 1. Alih Bahasa, Jaka Wasana, Kirbrandoko; Editor, Suryadi S. Jakarta: Binarupa Aksara.

www.idx.co.id ; Bursa Efek Indonesia 